\title{
APATITE SHELLS OF THE DEVONIAN FORAMINIFERS (SAFYANOVSKY COPPER-SULPHIDE DEPOSIT, MIDDLE URAL)
}

\author{
Elena Industrovna Soroka, \\ soroka@igg.uran.ru \\ Lyubov' Vladimirovna Leonova, \\ Ivleonova@yandex.ru \\ Artemiy L'vovich Anphimov
}

\author{
Zavaritsky Institute of Geology and Geochemistry \\ of the Ural Branch of the Russian Academy of Sciences \\ Ekaterinburg, Russia
}

\begin{abstract}
Relevance of the work is due to the possibility of a detailed study of Devonian foraminifers with apatite shells and the reconstruction of specific conditions for their formation. Foraminifer shells are morphologically similar to Parathurammina aff. tamarae L. Petrova, 1981, the Eifelian-the Givetian, which were found in thin sections of samples of carboniferous and chiselly aleuropelites of the ore-bearing strata of the Safyanovsky copper-sulphide deposit (Middle Urals) for the first time.

Purpose of work. Detailed study of the shells of Devonian foraminifers similar to Parathurammina aff. tamarae L. Petrova, 1981, as well as reconstruction of sedimentation conditions for carboniferous and chiselly rocks of the ore-bearing strata of the Safyanovsky copper-sulphide deposit.

Research methodology. Shells were studied in thin sections of carboniferous and chiselly aleuropelite samples. The detailed study of morphology and composition of the shells was carried out using a scanning electron microscope JSM-6390LV (JEOL) with an energy-dispersive spectrometer Inca Energy 450, an electron microscope Tescan and an electron probe microanalyzer Cameca SX100.

Results. Size and morphology of the shells were determined; it was also found that the walls of the shells of the studied foraminifers were represented by fluorapatite. It was assumed that initially they were calcareous, and subsequently were replaced by apatite and quartz. However, more detailed studies did not reveal traces of substitution of carbonate rock for apatite.

Conclusions. Compared with Parathurammina aff. tamarae L. Petrova, 1981, shells have a reduced size and a smaller number of fauces, which can be explained by unfavorable habitats in a shallow sea basin, where carbonate sedimentation was suppressed by a significant influx of volcanic material. The presence of sulfide minerals in nucleus of shells may indicate to the specific habitat ( $\mathrm{pH}$ of the environment, salinity of supra-bottom water) of foraminifers. Findings of fossils of green, siphon algae together with studied foraminifers indicate that formation of the original substrate took place in near-surface layers (up to $200 \mathrm{~m}$ ) of the photic zone of seas.
\end{abstract}

Keywords: Middle Urals, Safyanovsky copper-sulphide deposit, fossils, Devonian foraminifers, fluorapatite.

I ntroduction

The Safyanovsky deposit is located in $10 \mathrm{~km}$ to the northeast of Rezh (town) within the East Ural lifted block, in the southern part of the Rezhevskaya structural and formation zone. It is confined to the southern part of the Boroukhinsky tectonic block composed of igneous-sedimentary rocks of the Devonian and Mississippian period (Fig. 1).

Igneous rocks of the ore-bearing strata are represented by andesites, dacites, rhyodacites and their tuffs. The rocks of the Boroukhinsky block along the Zabolotsky thrusting of the northwestern dip superpose the limestones of the Carbonic period of the Pokrovsko-Mironovsky block. Along the Rezhevskoy mass overthrust of western dip, they are covered with limestones of the Middle-Upper Devonian, igneous-sedimentary rocks of the Upper Devonian; they also border with serpentinites of the Rezhevskoy massif $\left(\mathrm{O}_{1}\right)$. The rocks were tectonic, brecciated affected and hydrothermally altered. The main ore-shoot of the deposit is developed with an open-cut mining and a mine. The southern flank of the deposit sharply wedges out, and the northern one goes to the series of apophyses, which are represented by massive pyrite, copper-zinc and veinlet-impregnated sulphide ores. The ore-bearing strata of the deposit have a thickness of about $500 \mathrm{~m}$.

Noncarbonate shells of foraminifers were found in carboniferous and chiselly rocks, as well as igneous-sedimentary rocks (Fig. 2, a, b) of the ore-bearing strata of the Safyanovsky deposit [1,2].

Objects of research, methods of study and discussion of results

Shells those are morphologically similar to Parathurammina aff. tamarae L. Petrova, 1981 [5], the Eifelian-the Givetian, were studied in thin sections of carboniferous and chiselly aleuropelite samples. The detailed studies of the morphology and composition of the shells were carried out in the laboratory of physical and chemical methods of the Institute of Geology and Geochemistry of the Ural Branch of the Russian Academy of Sciences. The studies conducted using a scanning electron microscope JSM-6390LV (JEOL) with an energy-dispersive spectrometer Inca Energy 450 (S. P. Glavatsky as an operator), an electron probe The Cameca SX100 microanalyzer (D. A. Zamyatin as an operator). The places for studies are the Mining Institute of the Perm Scientific Center of the Ural Branch of the Russian Academy of Sciences and the mineralogy laboratory (Tescan electron microscope with E. P. Chirkova as an operator). By scanning electron microscopy over 10 shells were studied; some images with high resolution were obtained that allows to fix the parts of microstructure of walls (Fig. 3, c, inset); 114 determinations were performed; energy-dispersive spectra from the walls of shells were obtained (Fig. 3, c) (58 spectra from 8 sites in total).

Shells are secretory and rounded. Their outer diameter is $0.1-0.21 \mathrm{~mm}$, the internal diameter is $0.08-0.18 \mathrm{~mm}$. They have a threeply wall of $0.005-0.028 \mathrm{~mm}$ thick, short papillose (sometimes, average length) fauces of $0.01-0.066 \mathrm{~mm}$ in height (Fig. 3, a, b); the number of fauces varies from 1-2 to 8; in total, the sizes of 23 shells were determined. In some shells, one can see the scar of attachment of organisms to the bottom. That may indicate a benthic community of these foraminifers [6].

In contrast to carbonate shells of foraminifers Parathurammina aff. tamarae L. Petrova, 1981, the found shells have a reduced size and a smaller number of fauces, which can be explained by unfavorable habitats in a shallow sea basin, where carbonate sedimentation was suppressed by a significant influx of volcanic material. Good preservation and frequent coating of shells with pelitic matter, as well as traces of sedimentation, show the burial of shells in shallow marine conditions near the habitat [6]. 


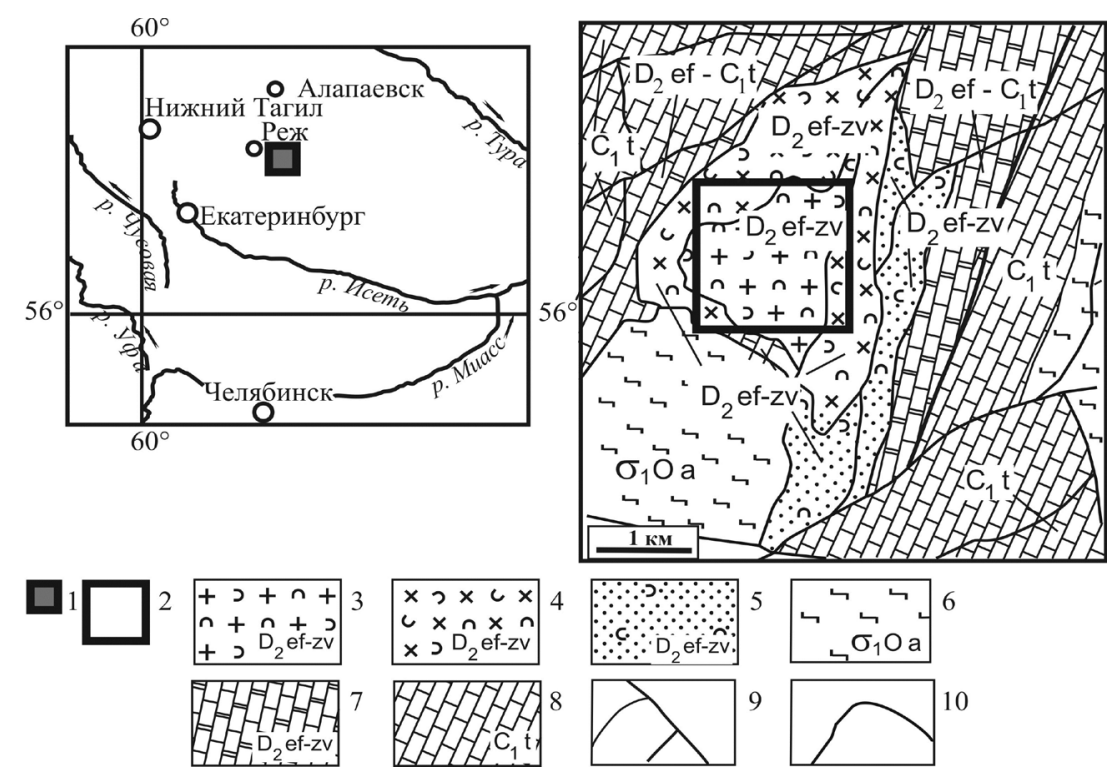

Figure 1. Areal map and geologic pattern of the Safyanovsky ore field. 1 - Safyanovsky ore field; 2 - open-cut mining; 3 - tuffs of acidic composition with beds of carboniferous and chiselly rocks; 4 - tuffs, igneous-sedimentary rocks with beds of limestones; 5 -igneous-sedimentary rocks, sandstones, aleurosandstones; 6 - serpentinites; 7 - marbled limestones; 8 - limestones; 9 - tectonic boundaries, dislocation with a break in continuity; 10 - geologic boundaries.

Рисунок 1. Обзорная карта и геологическая схема Сафьяновского рудного поля. 1 - Сафьяновское рудное поле; 2 - карьер; 3 туфы кислого состава с прослоями углеродисто-кремнистых пород; 4 - туфы, вулканогенно-осадочные породы с прослоями известняков; 5 - вулканогенно-осадочные породы, песчаники, алевропесчаники; 6 - серпентиниты; 7 - мраморизованные известняки; 8 - известняки; 9 - тектонические границы, разрывные нарушения; 10 - геологические границы.
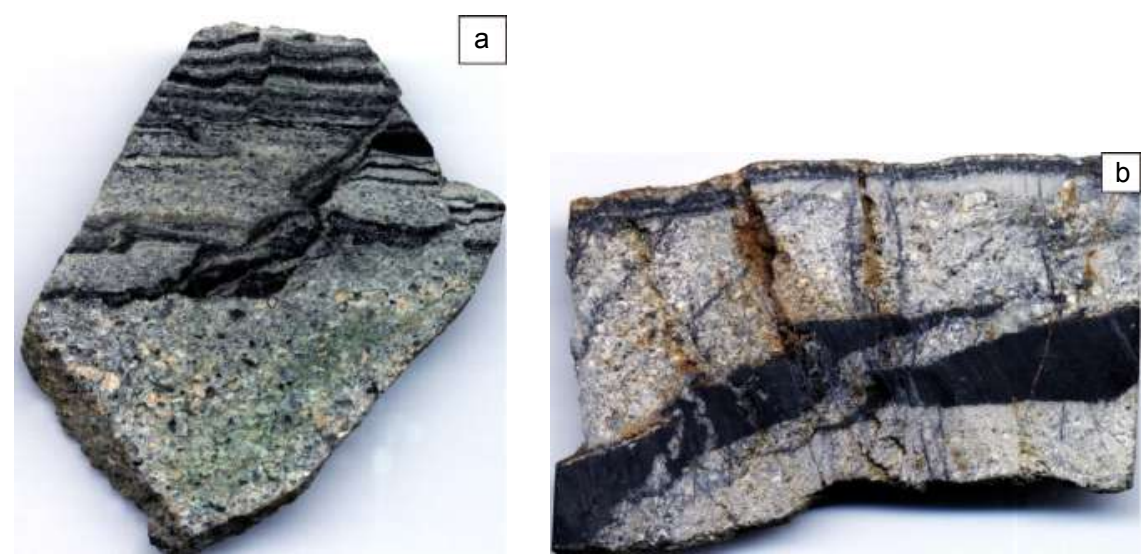

Figure 2. Graded bedding and rolling contacts in carboniferous and chiselly rocks of the Safyanovsky deposit. a - sandstone, horizon is $157 \mathrm{~m}$; b-sandstone, horizon is $100 \mathrm{~m}$ (open-cut mining based, $200 \mathrm{~m}$ - mine face). The rocks occur in a section in the form of benches with a thickness from 0.1 to $1.5 \mathrm{~m}$ [3]. They are represented by psephitomeric psammite tuffites, crystal-lithoclastic and pelitolite differences, and are composed of fragments of quartz, plagioclase crystals, subrounded fragments of rhyodacites. They contain shells of foraminifers, radiolarians, accumulations of algal residues and carbonaceous matter with definable residues of siphon algae [4]. The basic finely dispersed mass consists of quartz, chlorite, plagioclase, mica, kaolinite, and carbonates. Sandstone deposits, which are also found in the ore-bearing stratum of the deposit, have graded bedding and sometimes rolling contacts with carboniferous and chiselly rocks (Fig. 2, a).

Рисунок 2. Градационная слоистость и волнистые контакты в кремнисто-углеродистых породах Сафьяновского месторождения. а песчаник, горизонт 157 м; б - песчаниоризонт 100 м (отсчет от забоя карьера, 200 м - забой). Породы залегают в разрезе в виде пачек мощностью от 0,1 до 1,5 м [3]. Они представлены псефито-псаммитовыми туфффитами, кристалло-литокластическими и пелитолитовыми разностями и сложены обломками кварца, кристаллами плагиоклаза, угловато-окатанными обломками риодацитов. Содержат раковины фораминифер, радиолярий, скопления водорослевых остатков и углеродистого вещества, причем встречаются определимые остатки сифоновых водорослей [4]. Основная тонкодисперсная масса состоит из кварца, хлорита, плагиоклаза, слюды, каолинита, карбонатов. Песчаниковые отложения, которые также встречаются в рудовмещающей толще месторождения, имеют градационную слоистость и местами волнистые контакты с кремнисто-углеродистыми породами (рис. 2, а).

The presence of sulphide minerals in the shells nuclei indicate the specific habitat conditions of these foraminifers. For example, shells can sometimes be filled with framboids (Fig. 4) formed due to the vital activities of sulfur bacteria ("mineralized bacteria") under conditions of oxygen deficiency [7].

Moreover, crystalline pyrite (Fig. 5, a), sphalerite and faded ores (Fig. 5, b) are also found in planes of foraminifer shells.

It was assumed that the shells of these foraminifers were originally calcareous, and subsequently were replaced by apatite and quartz [6]. As for the pseudomorphic replacement of fossils is concerned, the results of experimental studies of the hydrothermal substitution of apatite carbonates have revealed that poriness of initial substance plays an important role in replacement of calcite 

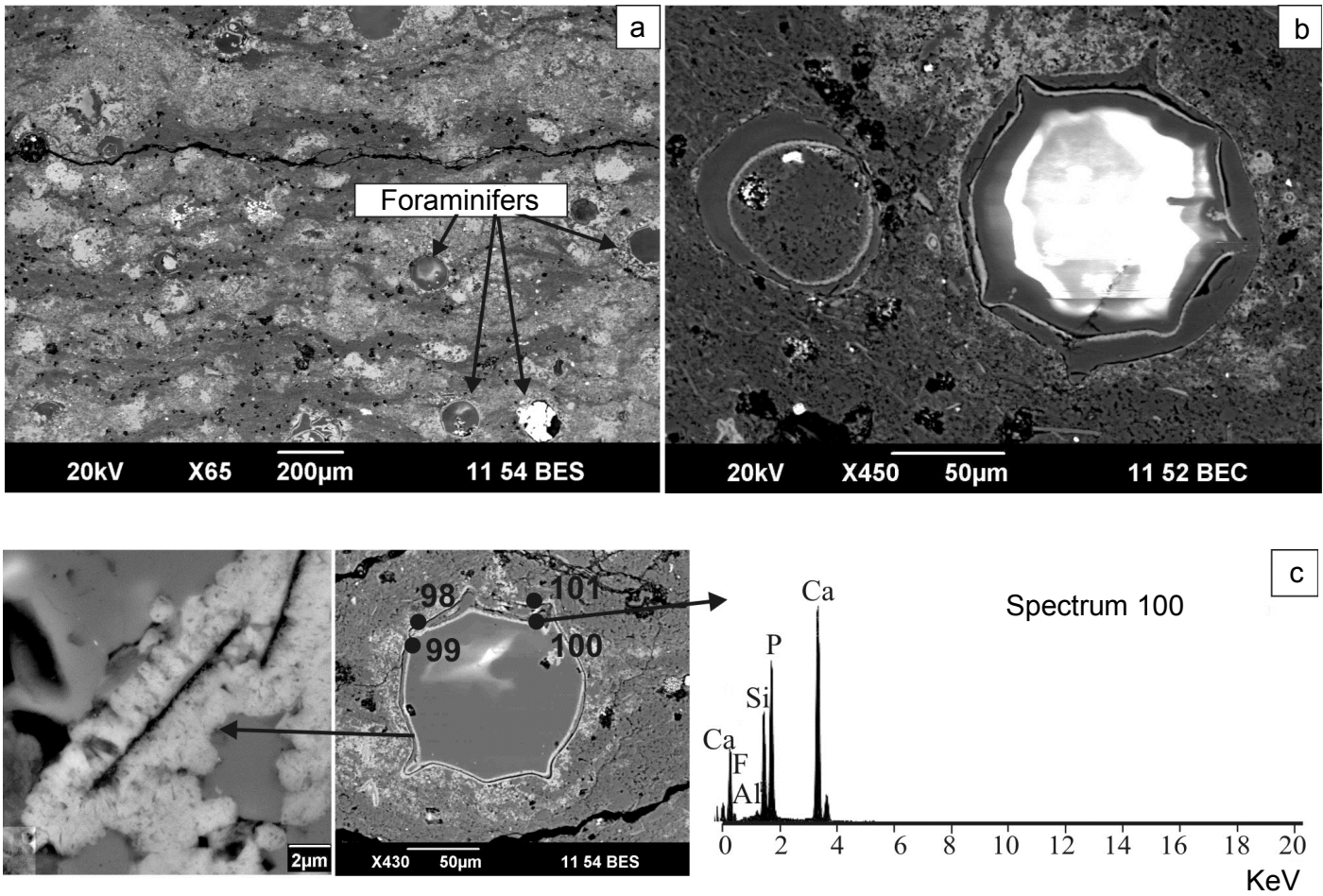

Figure 3. Photos made with a scanning electron microscope. a - foraminifer shells in carboniferous and chiselly aleuropelites; $b$ - morphological structure of the shells; c - foraminifer shells with fluorapatite wall and energy-intensive spectrum (right), fibrous microstructure of the wall is on the right inset map.

Рисунок 3. СэМ-фото. а - раковины фораминифер в углеродисто-кремнистых алевропелитах; б - морфологическое строение раковин; в - раковина фораминиферы с фторапатитовой стенкой и ЭДС-спектр (справа), на врезке слева волокнистая микроструктура стенки.

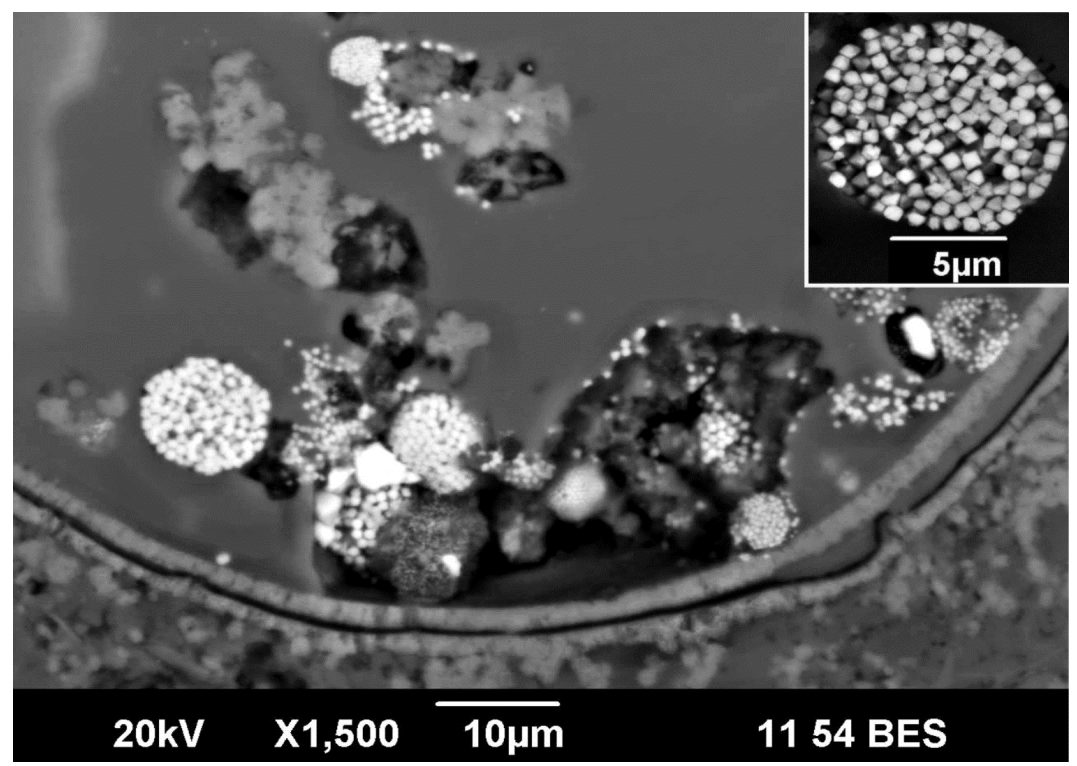

Figure 4. There is a framboidal pyrite in planes of foraminifer shells.

Рисунок 4. В полостях раковин фораминифер встречается фрамбоидальный пирит.

and aragonite [8]. Moreover, the uneven weeping of the solution in the rock is also important. With slower and uneven weeping and fragmentary substitution in aleuropelites, definable fragments of fossils can be retained, which could be destroyed in the course of sedimentation.

But the detailed studies of the found shells did not reveal any traces of substitution of apatite carbonate. According to semi-quantitative analysis, the ratio of $\mathrm{Ca} / \mathrm{P}$ in the walls of shells varies from 1.6 to 1.9 . Almost at all points of determinations, there is F from 7 to 3 atom per cent in the walls of shells. The studies with the use of microprobe made it possible to refine the contents of $\mathrm{F}$ and confirmed the hypothesis that the wall of the shell consists of fluorapatite (Table).

It should be noted that the inner part of the shell and the space between the apatite layers of the wall consist of silica (Fig. 3, b). The Table shows the wall composition of the shell, which contains a certain amount of $\mathrm{SiO}_{2}$, as well as the analysis of fluorapatite 

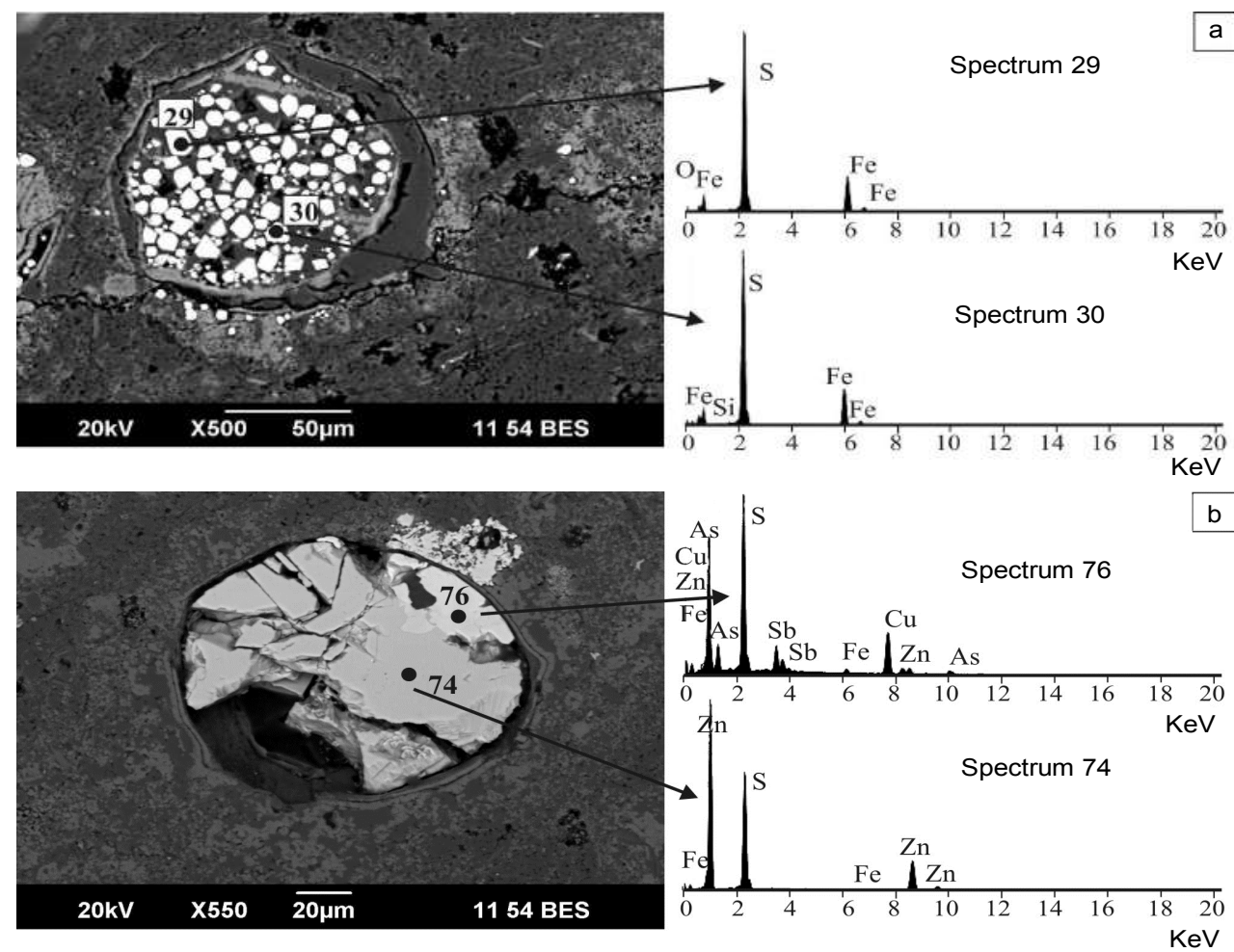

Figure 5. Sulphide minerals found in planes of foraminifer shells; composition of elements is shown on the energy-intensive spectra. a - pyrite crystals; $b$ - sphalerite and faded ores.

Рисунок 5. Сульфидные минералы, установленные в полостях раковин фораминифер, элементный состав показан на эдСспектрах. а - кристаллы пирита; б - сфралерит и блеклые руды.

Composition of the apatite wall of the shell according to microprobe analysis.

Состав апатита стенки раковины по данным микрозондового анализа.

\begin{tabular}{|c|c|c|c|c|c|}
\hline \multirow{2}{*}{ Components wt. \% } & \multicolumn{5}{|c|}{ Numerical order of the analysis } \\
\hline & 1 & 2 & 3 & 4 & 5 \\
\hline $\mathrm{SiO}_{2}$ & 0.43 & 1.35 & 2.32 & 0.15 & 0.03 \\
\hline $\mathrm{P}_{2} \mathrm{O}_{5}$ & 40.98 & 36.86 & 35.46 & 32.81 & 41.97 \\
\hline $\mathrm{Al}_{2} \mathrm{O}_{3}$ & 0.02 & 0.24 & 0.35 & 0.36 & 0.04 \\
\hline $\mathrm{MgO}$ & 0.02 & 0.14 & 0.21 & 0.16 & 0.05 \\
\hline $\mathrm{CaO}$ & 53.98 & 52.4 & 51.1 & 46.45 & 55.64 \\
\hline $\mathrm{MnO}$ & 0.01 & 0.04 & 0.03 & 0.02 & 0.2 \\
\hline $\mathrm{FeO}$ & 0 & 0.06 & 0.13 & 0.96 & 0.55 \\
\hline $\mathrm{Na}_{2} \mathrm{O}$ & 0.27 & 0.25 & 0.35 & 0.35 & 0 \\
\hline $\mathrm{SrO}$ & 0.09 & 0.12 & 0.08 & 0.26 & 0.03 \\
\hline $\mathrm{F}$ & 3.32 & 4.35 & 4.13 & 4.01 & 2.29 \\
\hline $\mathrm{Cl}$ & 0.43 & 0.05 & 0.03 & 0.05 & 0.41 \\
\hline $\mathrm{SO}_{3}$ & 0.59 & 0.42 & 0.43 & 1.07 & 0.04 \\
\hline Amount & 100.14 & 96.28 & 94.85 & 86.65 & 101.24 \\
\hline \multicolumn{6}{|c|}{ Elements, atom per cent } \\
\hline $\mathrm{Si}$ & 0.17 & 0.56 & 0.97 & 0.07 & 0.01 \\
\hline $\mathrm{P}$ & 13.74 & 12.85 & 12.56 & 12.76 & 14.04 \\
\hline $\mathrm{Al}$ & 0.01 & 0.01 & 0.17 & 0.2 & 0.02 \\
\hline $\mathrm{Mg}$ & 0.01 & 0.08 & 0.13 & 0.11 & 0.03 \\
\hline $\mathrm{Ca}$ & 22.92 & 23.13 & 22.91 & 22.86 & 23.55 \\
\hline $\mathrm{Mn}$ & 0 & 0.01 & 0.01 & 0.01 & 0.07 \\
\hline $\mathrm{Fe}$ & 0 & 0.02 & 0.04 & 0.37 & 0.18 \\
\hline $\mathrm{Na}$ & 0.21 & 0.2 & 0.28 & 0.32 & 0 \\
\hline $\mathrm{Sr}$ & 0.02 & 0.03 & 0.02 & 0.07 & 0.01 \\
\hline $\mathrm{F}$ & 4.16 & 5.67 & 5.47 & 5.83 & 2.86 \\
\hline $\mathrm{Cl}$ & 0.29 & 0.02 & 0.04 & 0.04 & 0.27 \\
\hline$S$ & 0.18 & 0.3 & 0.14 & 0.37 & 0.01 \\
\hline 0 & 58.3 & 57.18 & 57.26 & 57.01 & 58.99 \\
\hline
\end{tabular}

Сорока Е. И. и др. Апатитовые раковины девонских фораминифер (Сафьяновское медноколчеданное месторождение, 37 Средний Урал) // Известия УГГУ. 2018. Вып. 3(51). C. 34-39. DOI 10.21440/2307-2091-2018-3-34-39 
from the matrix of the rock (Table, analysis 5). Actually the $\mathrm{SiO}_{2}$ content is low in the fluoropatite from the rock. Probably, the matrix affects the wall of the shell, because thickness of the wall is extremely small. It should be noted that the amount of $\mathrm{P}$ and $\mathrm{O}$ is somewhat underestimated compared to the standard fluorapatite (analysis 1) and apatite in the rock (analysis 5). The F content is high enough, higher than the standard one. It can be assumed that the positions of phosphorus in the apatite trellis of the shell wall can be partially occupied by carbonate ion [9].

Biologically, phosphate substance of bones and teeth is usually represented by the apatite group [9]. Hydroxylapatite exists in dentin - a solid base of human teeth - it forms the crystalline basis of hard tissue. In addition, phosphates, including hydroxylapatite and carbonate, exist in uroliths that can appear in human body [10]. It is established that $\mathrm{pH}$ of the solution has a significant effect on the composition of the forming stones [11].

It is known that the conodont elements, which are the mineralized remains of the parts of the conodont's mouthparts (an extinct group of marine organisms), consist of different layers of fluorapatite and collagen protein that form during the life of organisms. Fluoride hydroxylapatite of the conodont elements is well studied, its crystal structure is specified, and the features of the elemental composition are revealed [12]. The studies of the mineral composition of hard tissues of the late Devonian conodont elements showed fluorapatite with an atomic ratio of $\mathrm{Ca} / \mathrm{P}=1.60-1.65$. In addition, some fluctuations in $\mathrm{Sr}$ content were noted [13]. Strontium exists in the walls of the shells of apatite foraminifers (Table) which we study.

Conclusions

According to [14], Devonian paraturamines with a secretion calcareous shell are found in the Petropavlovskaya and Turinskaya structural and facial zones of the eastern slope of the Urals in biomorphic tabular-amphipore limestones and rarely in clayey limestones and chalky clay. Foraminifers with noncarbonate agglutinated shell and siliceous and ferruginous cement are known in sedimentary deposits of the Triassic of Western Siberia [15]. Thus, Devonian foraminifers with a non-carbonate secretion apatite shell are found for the first time in igneous-sedimentary rocks of the eastern slope of the Urals. Probably, some specific conditions of sedimentation are typified for igneous-sedimentary rocks of the ore-bearing strata of the Safyanovsky deposit: $\mathrm{pH}$ medium and salinity of the supra-bottom water. In addition, the findings of fossils of green and siphon algae indicate that formation of initial substance took place in shallow conditions (up to $200 \mathrm{~m}$ ) of the photographic zone of seas.

The work was carried out within the framework of the state task of the Zavaritsky Institute of Geology and Geochemistry of the Ural Branch of the Russian Academy of Sciences (State registration No AAAA-A18-118052590028-9 and AAAA-A18-118052590032-6).

\section{REFERENCES}

1. Chuvashov B. I, Anfimov A. L., Soroka E. I., Yaroslavtseva N. S. 2011. Novyye dannyye o vozraste rudovmeshchayushchey tolshchi Saf'yanovskogo mestorozhdeniya (Sredniy Ural) na osnove foraminifer [New data on the age of the ore-bearing sequence of the Safyanovsky deposit (Middle Urals) on the basis of foraminifers]. Doklady Akademii nauk [Doklady Earth sciences], vol. 439, no 5. pp. 648-650.

2. Anfimov A. L., Soroka E. I., Yaroslavtseva N. S., Glavatskikh S. P. 2011, Genezis uglerodisto-kremnistykh prosloyev v rudovmeshchayushchey vulkanogenno-osadochnoy tolshche Saf'yanovskogo mednokolchedannogo mestorozhdeniya (Sredniy Ural) [Genesis of carbon-siliceous interlayers in the ore-bearing igneous-sedimentary stratum of the Safianovsky copper-pyrite deposit (Middle Urals)]. Vulkanizm i geodinamika: $V$ Vserossiyskiy simpozium po vulkanologii i paleovulkanologii [Volcanism and geodynamics: V All-Russian academic conference on volcanology and paleovolcanology]. Ekaterinburg, pp. 474-476.

3. Yaroslavtseva N. S., Maslennikov V. V., Safina N. P. et al. 2012, Uglerodsoderzhashchiye alevropelity Saf'yanovskogo medno-tsinkovokolchedannogo mestorozhdeniya (Sredniy Ural) [Carboniferous aleuropelites of the Safyanovsky copper-zinc-pyrite deposit (Middle Urals)]. Litosfera [Litosfera], no 2, pp. 106-123.

4. Soroka E., Leonova L., Pritchin M., Maidl T. 2018, Fossil algae as indicators of the depositional environment. Proceedings of Kazan Golovkinsky-2017. Bologna, pp. 321-325.

5. Petrova L. G. 1981, Foraminifery srednego devona vostochnogo sklona Urala. Paleozoy Zapadno-Sibirskoy nizmennosti i yeye gornogo obramleniya [Foraminifera of the Middle Devonian of the eastern slope of the Urals. Paleozoic of the West Siberian lowland and its mountain range]. Novosibirsk, pp. 81-101.

6. Chuvashov B. I., Anfimov A. L., Soroka E. I., Yaroslavtseva N. S. 2012, Devonskiye foraminifery s nekarbonatnoy rakovinoy v rudovmeshchayushchey tolshche Saf'yanovskogo mestorozhdeniya (Sredniy Ural) [Devon foraminifers with a non-carbonate shell in the ore-bearing strata of the Safyanovsky deposit (Middle Urals)]. Litosfera [Litosfera], no. 5, pp. 114-125.

7. Berberian T. K. 1983, Framboid-piritnyye agregaty v rudakh kolchedannykh mestorozhdeniy i ikh geneticheskoye i poiskovoye znacheniye [Framboid-pyrite aggregates in ores of pyrite deposits and their genetic and search value]: extended abstract of PhD thesis. Novocherkassk, $165 \mathrm{p}$.

8. Kasioptas A., Geisler Th., Perdikouri Ch., Trepmann C., Gussone N., Putnis A. 2011, Polycrystalline apatite synthesized by hydrothermal replacement of calcium carbonates. Geochemica et Cosmochemica Acta, vol. 75, pp. 3486-3500.

9. Deer W. A., Howie R. A., Zussman J. 1966, Rock-forming minerals. Moscow, vol. 5, 405 p.

10. Potapov S. S., Parshina N. V., Potapov D. S. 2005, Neskol'ko primerov morfologii, stroyeniya i mineralogii urolitov zhiteley Chelyabinskoy oblasti [Some examples of morphology, structure and mineralogy of urolites of Chelyabinsk region residents]. Vestnik Ural'skogo otdeleniya Rossiyskogo mineralogicheskogo obshchestva [Bulletin of the Ural Branch of the Russian Mineralogical Society], no. 4, pp. 96-99.

11. Golovanova O. A. 2010, Termodinamicheskoye modelirovaniye patogennogo mineraloobrazovaniya [Thermodynamic modeling of pathogenic mineral formation]. Mineraly: stroyeniye, svoystva, metody issledovaniya [Minerals: structure, properties, research methods]. Proceedings from II All-Russian youth scientific conference (March 23-26). Miass, pp. 139-141.

12. Katvala E. C., Henderson C. M. 2012, Chemical element distributions within conodont elements and their functional implications. Paleobiology, vol. 38, pp. 447-458. DOI 10.1666/11038.1.

13. Zhuravlev A. V., Shevchuk S. S. 2017, Strontium distribution in Upper Devonian conodont elements: a palaeobiological proxy. Rivista Italiana di Paleontologia e Stratigrafia, vol. 123 (2), pp. 203-210.

14. Zadorozhny V. M. 1987, Foraminifery i biostratigrafiya devona Zapadno-Sibirskoy plity $i$ yeye skladchatogo obramleniya [Foraminifers and biostratigraphy of the Devonian of the West Siberian Plate and its folded frame]. Trudy instituta geologii i geofiziki SO AN SSSR [Proceedings of the Institute of Geology and Geophysics of the Siberian Branch of the Academy of Sciences of the USSR], issue 680, $126 \mathrm{p}$.

15. Lutova Z. V. 1981, Stratigrafiya i foraminifery kelloveya severa Sredney Sibiri [Stratigraphy and foraminifers Callovian north of Central Siberia]. Moscow, $134 \mathrm{p}$. 


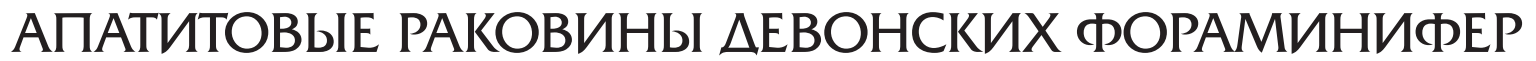 (САФЬЛНОВСКОЕ МЕАНОКОЛЧЕААННОЕ МЕСТОРОЖАЕНИЕ, СРЕАНИЙ УРАИ)
}

\author{
Елена Индустровна Сорока, \\ soroka@igg.uran.ru \\ Любовь Владимировна Леонова, \\ Ivleonova@yandex.ru \\ Артемий Львович Анфимов
}

\author{
Институт геологии и геохимии \\ им. академика А. Н. Заварицкого УрО РАН \\ Россия, Екатеринбург, ул. Академика Вонсовского, 15
}

\begin{abstract}
Актуальность работы обусловлена возможностью детального изучения девонских фораминисер с апатитовыми раковинами и реконструкции специсических условий их образования. Раковины фораминисер, морсологически похожие на Parathurammina aff. tamarae L. Petrova, 1981, эйсель-живет, были обнаружены в тонких срезах образцов углеродисто-кремнистых алевропелитов рудовмешаюшей толши Сафьяновского медноколчеланного месторожления (Средний Ураи) впервые.

Цель работы: детаиьное изучение раковин девонских фораминисер, похожих на Parathurammina aff. tamarae L. Реtrova, 1981, и реконструкция условий осадконакопления углеродисто-кремнистых пород рудовмешаюшей толши Сафьяновского медноколчеданного месторождения.

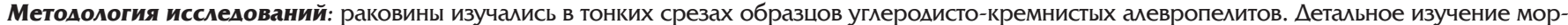
фологии и состава раковин проводилось при помощи сканируюшего электронного микроскопа JSM-6390LV (JEOL) с ЭАC-cпектрометром Inca Energy 450, электронного микроскопа Tescan и электронно-зондового микроанаиизатора Cameca SX100.

Результаты: были определены размеры и морфология раковин, также установлено, что стенки раковин изучаемых срораминисер представлены срторапатитом. Предполагалось, что изначально они были известковистыми, а впоследстви были замещены апатитом и кварцем, однако более метальные исследования не выявили следов замещения карбоната апатитом.

Выводы: по сравнению с Parathurammina aff. tamarae L. Petrova, 1981, раковины имеют уменьшенные размеры и меньшее количество устьев, что можно объяснить неблагоприятными условиями обитания в мелководном морском бассейне, в котором карбонатное осацконакопление было подавлено значительным привносом вулканического материала. О специсричных условиях обитания (рН среды, минерализация придонных вод) фораминисер может свилетельствовать присутствие сульфидных минералов в ялрах раковин. Находки фроссилий зеленых, сисооновых водорослей совместно с изучаемыми фораминисерами свилетельствуют о том, что отложение первоначаиьного субстрата проходило в малоглубинных условиях (Ао 200 м) фотической зоны морей.
\end{abstract}

Киючевые слова: Средний Урал; Сафьяновское медноколчеданное месторождение; фоссилии; девонские фрораминисеры; сторапатит.

Работа выполнена в рамках темы государственного задания ИГГ УрО РАН (№ гос. регистрации ААААA18-118052590028-9 u AAAA-A18-118052590032-6).

\section{ЛИТЕРАТУРА}

1. Чувашов Б. И, Анфимов А. Л., Сорока Е. И., Ярославцева Н. С. Новые данные о возрасте рудовмещающей толщи Сафьяновского месторождения (Средний Урал) на основе фораминифер // ДАН. 2011. Т. 439, № 5. С. 648-650.

2. Анфимов А. Л., Сорока Е. И., Ярославцева Н. С., Главатских С. П. Генезис углеродисто-кремнистых прослоев в рудовмещающей вулканогенно-осадочной толще Сафьяновского медноколчеданного месторождения (Средний Урал) // Вулканизм и геодинамика: V Всерос. симпоз. по вулканологии и палеовулканологии. Екатеринбург: Ин-т геологии и геохимии УрО РАН, 2011. С. 474-476.

3. Ярославцева Н. С., Масленников В. В., Сафина Н. П. и др. Углеродсодержащие алевропелиты Сафьяновского медно-цинковоколчеданного месторождения (Средний Урал) // Литосфрера. 2012. № 2. С. 106-123.

4. Soroka E., Leonova L., Pritchin M., Maidl T. Fossil algae as indicators of the depositional environment // Proceedings of Kazan Golovkinsky-2017. Bologna: Filodiritto Editore, 2018. P. 321-325.

5. Петрова Л. Г. Фораминиферы среднего девона восточного склона Урала // Палеозой Западно-Сибирской низменности и ее горного обрамления. Новосибирск: Наука, 1981. С. 81-101.

6. Чувашов Б. И., Анфимов А. Л., Сорока Е. И., Ярославцева Н. С. Девонские фораминиферы с некарбонатной раковиной в рудовмещающей толще Сафьяновского месторождения (Средний Урал) // Литосфрера. 2012. № 5. 114-125.

7. Берберьян Т. К. Фрамбоид-пиритные агрегаты в рудах колчеданных месторождений и их генетическое и поисковое значение: авторефр. дис. канд. геол.-минерал. наук. Новочеркасск, 1983. 165 с.

8. Kasioptas A., Geisler Th., Perdikouri Ch., Trepmann C., Gussone N., Putnis A. Polycrystalline apatite synthesized by hydrothermal replacement of calcium carbonates // Geochemica et Cosmochemica Acta. 2011. Vol. 75. P. 3486-3500.

9. Дир У. А., Хауи Р. А., Зусман Дж. Породообразующие минералы. М.: Мир, 1966. Т. 5. 405 с.

10. Потапов С. С., Паршина Н. В., Потапов Д. С. Несколько примеров морфологии, строения и минералогии уролитов жителей Челябинской области // Вестник УрО РМО. 2005. № 4. С. 96-99.

11. Голованова О. А. Термодинамическое моделирование патогенного минералообразования // Минералы: строение, свойства, методы исследования: сб. материалов II Всерос. молодеж. науч. конф. (23-26 марта). Миасс, 2010. С. 139-141.

12. Katvala E. C., Henderson C. M. Chemical element distributions within conodont elements and their functional implications // Paleobiology. 2012. Vol. 38. P. 447-458. doi:10.1666/11038.1.

13. Zhuravlev A. V., Shevchuk S. S. Strontium distribution in Upper Devonian conodont elements: a palaeobiological proxy // Riv. It. Paleontol. Strat. 2017. Vol. 123 (2). P. 203-210.

14. Задорожный В. М. Фораминиферы и биостратиграфия девона Западно-Сибирской плиты и ее складчатого обрамления // Тр. ИГиГ СО АН СССР. Новосибирск: Наука, 1987. Вып. 680. 126 с.

15. Лутова 3. В. Стратиграфия и фораминиферы келловея севера Средней Сибири. М.: Наука, 1981. 134 с. 